\title{
Nutritional Requirement of Sugarcane Cultivars
}

\author{
Vinicius S. G. da Silva ${ }^{1}$, Mauro W. de Oliveira ${ }^{1}$, Vilma M. Ferreira ${ }^{1}$, Terezinha B. A. Oliveira ${ }^{1}$, Elaine R. Galvão ${ }^{2}$, \\ Aleksandro F. da Silva ${ }^{3} \&$ Polyana A. S. Machado ${ }^{4}$ \\ ${ }^{1}$ Centro de Ciências Agrárias, Universidade Federal de Alagoas, Rio Largo, AL, Brazil \\ ${ }^{2}$ Departamento de Tecnologia e Ciências Sociais, Universidade do Estado da Bahia, Juazeiro, BA, Brazil \\ ${ }^{3}$ Departamento de Agronomia, Universidade Federal Rural de Pernambuco, Recife, PE, Brazil \\ ${ }^{4}$ Departamento de Zootecnia, Universidade Federal de Viçosa, Viçosa, Minas Gerais, MG, Brazil \\ Correspondence: Vinicius S. G. da Silva, Centro de Ciências Agrárias, Universidade Federal de Alagoas, Rio \\ Largo, AL 51100-000, Brazil. Tel: 55-81-99572-3906. E-mail: vinicius.agro2008.1@gmail.com
}

Received: January 3, 2018

Accepted: February 11, $2018 \quad$ Online Published: March 15, 2018

doi:10.5539/jas.v10n4p361

URL: https://doi.org/10.5539/jas.v10n4p361

\begin{abstract}
Sugarcane produces a large amount of biomass, extracts and accumulates high amounts of nutrients. In the literature the nutritional requirements for most cultivated varieties in the past are found, however there is little information on the new varieties currently planted. The objective of this study was to evaluate the nutritional requirement of four sugarcane varieties, currently very planted, in the cycles of plant-cane, first and second ratoon. The study was installed in a Yellow Oxisol. The experimental design was a randomized block design, with five replications, and four treatments: RB867515, RB92579, SP813250 and VAT90212. During maturation of the cane, in the three evaluation cycles, the productivity of natural biomass and the nutritional requirement of macronutrients of the varieties were determined. It was evidenced that the cultivars of sugarcane are of high productive potential and resemble the accumulation of biomass, observing a yield of 158,128 and $107 \mathrm{tha}^{-1}$ in the cycles of plant-cane, first and second ratoon. Regarding the nutritional requirement, the varieties did not differ among them and expressed the following order of need in the plant-cane $\mathrm{K}>\mathrm{N}>\mathrm{Ca}>\mathrm{Mg}>\mathrm{S}>\mathrm{P}$, in the first and second ratoon, the sequence observed was $\mathrm{K}>\mathrm{N}>\mathrm{Ca}>\mathrm{S}>\mathrm{Mg}>\mathrm{P}$.
\end{abstract}

Keywords: biomass yield, nutrients extraction, nutritional efficiency, Saccharum spp.

\section{Introduction}

Sugarcane is one of the world's most bioenergy crops, with a production of approximately 2.5 million $\mathrm{Mg}$ year ${ }^{-1}$. Brazil, considered as the largest producer, has approximately 9 million ha cultivated with sugarcane and generates about $25 \%$ of world production (Bellé et al., 2017). In spite of the high production, Brazilian sugarcane plantations have presented low yields, demonstrated by average less than $59 \mathrm{t} \mathrm{ha}^{-1}$, due among other factors, inadequate fertilization that does not meet the nutritional needs of the crop, a result of lack of nutritional knowledge for new varieties (Oliveira et al., 2012; Santos et al., 2017; Silva et al., 2017a).

Due to its large production of biomass, the cane exports and accumulates high amounts of nutrients from the soil. Based on a compilation by Oliveira et al. (2007) for a production of $120 \mathrm{Mg} \mathrm{ha}^{-1}$ of biomass, the accumulation of nutrients in the aerial part of the plants is respectively 150,40,180, 90, 50 and $40 \mathrm{~kg}$ of nitrogen $(\mathrm{N})$, phosphorus $(\mathrm{P})$, potassium $(\mathrm{K})$, calcium $(\mathrm{Ca})$, magnesium $(\mathrm{Mg})$ and sulfur $(\mathrm{S})$. In this way, to adequate nutritional management is important for sugarcane crop to become more productive and competitive.

In this context, studies that evaluate the nutritional demand of sugarcane varieties are fundamental, since fertilization constitutes a significant part of the production costs of the sugarcane industry (Silva et al., 2017b), however, studies that identify nutrient requirements have not been carried out frequently, and the information available mostly refers to varieties that are no longer planted (Oliveira et al., 2010). The results of these studies have shown that cultivars may present variations in nutrient extraction (Oliveira et al., 2010; Calheiros et al., 2011).

These differences can be largely associated to the morphological and physiological characteristics of the varieties associated with nutritional uptake, including the nutrient influx rate, the Michaelis-Mentem constant and the minimum concentration, below which there is no net inflow (Malavolta et al., 1997; Marshner, 2012). 
Another aspect that influences nutrient absorption is the climatic variations from year to year, especially the volume and distribution of rainfall, these factors directly interfere in the water availability to the plant and in the nutritional demand of the cane, with great reflection in the metabolic processes and in biomass production (Silva et al., 2017c, 2017d). The soil explored by the cane root system and its absorptive capacity also decreases with the cycles, being higher in the cane-plant and decreasing in the ratoon. For these reasons, it is recommended to evaluate the nutritional demands of cane for more than one harvest cycle, in order to contemplate the climatic, edaphic and nutritional variations of sugarcane (Silva et al., 2017a).

The identification of the nutrients demand related to the production of stalks in the varieties currently used in the Brazilian sugarcane plantations is indispensable to obtain high productivity, as well as to correctly recommend varieties for conditions of low soil nutrient supply (Oliveira et al., 2010), thus allow efficiency use of fertilizers and other inputs, with consequent reduction in costs and increased efficiency of the production system. The objective of this work was to quantify the macronutrient requirement in four sugarcane varieties (RB867515, RB92579, SP-813250 and VAT90212) in the cycles of plant-cane, first and second ratoon.

\section{Material and Methods}

\subsection{Characteristics of the Experimental Area}

The experiment was conducted in the field, located in the municipality of Anadia $\left(9^{\circ} 48^{\prime} 24^{\prime \prime} \mathrm{S}, 36^{\circ} 6^{\prime} 55^{\prime \prime} \mathrm{W}\right)$, Zona da Mata de Alagoas, Brazil (Figure 1), which climate according to Koppen classification is characterized as tropical rainy, with dry summers. An annual rainfall average was $1,200 \mathrm{~mm}$, but during the trial, accumulated precipitation was $1.873 \mathrm{~mm}$ in the plant-cane cycle (September of the year of 2009 to December of the year of 2010), $1.931 \mathrm{~mm}$ in the first ratoon (December of the year of 2010 to December of the year of 2011) and 849.5 $\mathrm{mm}$ in the second ratoon (December of the year of 2011 to December of the year of 2012) (Figure 2). The annual temperature average is $29^{\circ} \mathrm{C}$. The local soil relief varies from plane to gently wavy (Silva et al., 2017a).

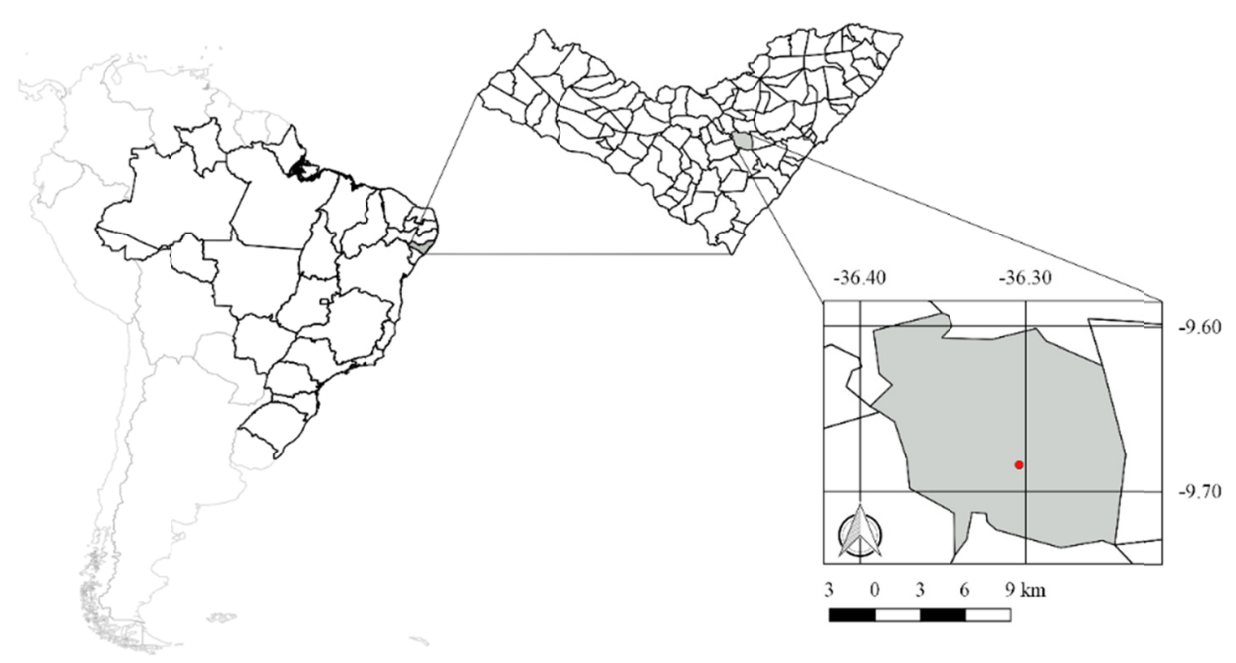

Figure 1. Location of the experimental area 


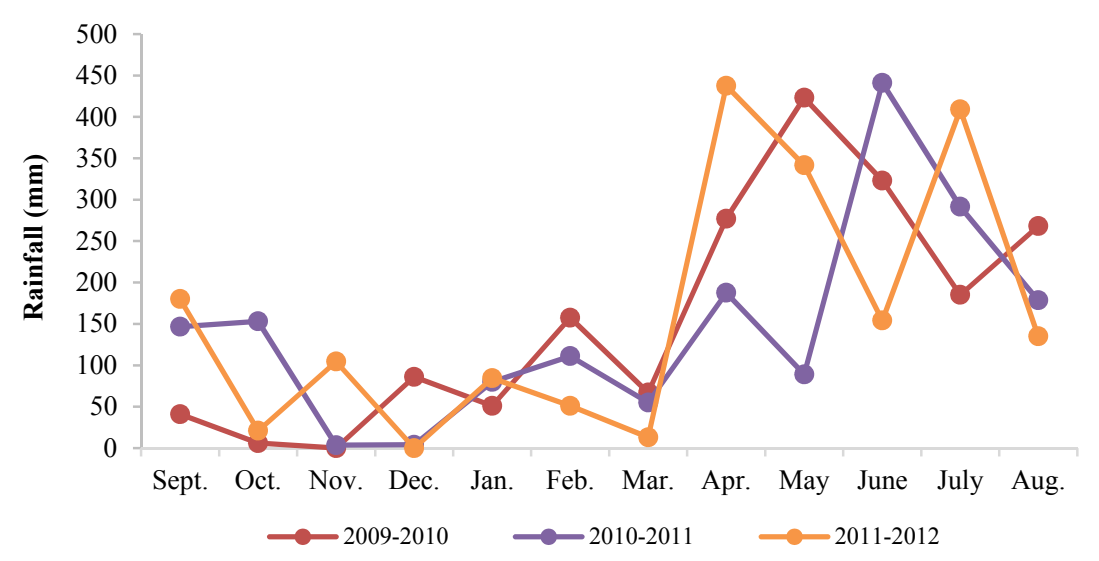

Figure 2. Monthly precipitation during the period studied

The soil of the experimental area was classified as a Yellow Oxisol (Embrapa, 2013). Prior to the installation of the study, soil sampling was carried out in the 0.0-0.2 and 0.2-0.4 m layers for the chemical characterization (Table 1), All analyzes were performed according to the methodologies described by Embrapa (2009).

Table 1. Soil chemical attributes of the experimental area at $0-20 \mathrm{~cm}$ and $20-40 \mathrm{~cm}$ (Silva et al., 2018)

\begin{tabular}{|c|c|c|c|c|c|c|c|}
\hline Layers & $\mathrm{pH}$ & $\mathrm{P}$ & $\mathrm{K}$ & $\mathrm{Ca}$ & $\mathrm{Mg}$ & $\mathrm{Al}$ & $\mathrm{H}+\mathrm{Al}$ \\
\hline$(\mathrm{cm})$ & $\mathrm{H}_{2} \mathrm{O}$ & \multicolumn{2}{|c|}{------ $\mathrm{mg} \mathrm{dm}^{-3}$-------- } & \multicolumn{4}{|c|}{ 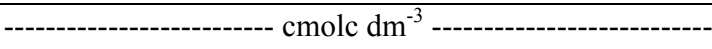 } \\
\hline $00-20$ & 5.9 & 103.0 & 40 & 1.8 & 0.8 & 0.0 & 3.80 \\
\hline $20-40$ & 5.0 & 21.6 & 20 & 0.6 & 0.3 & 0.6 & 4.62 \\
\hline
\end{tabular}

\subsection{Soil Preparation and Cane Planting}

From the results of the soil analysis (Table 1), the soil acidity was corrected using dolomitic limestone, calculated by the method that aims to increase saturation by base to $60 \%$, according to Oliveira et al. (2007). After the application of limestone, the soil was plowed and meshed, and then the grooves were opened. The planting was done manually in September 2009. Sugarcane stalks with three buds per grinder were distributed in the planting grooves in order to reach 18 buds per meter.

The fertilization was based on the results of the soil analysis, and followed the recommendations of Oliveira et al. (2007). In the cane-plant cycle all plots received 60,100 and $150 \mathrm{~kg} \mathrm{ha}^{-1}$ of $\mathrm{N}, \mathrm{P}_{2} \mathrm{O}_{5}$ and $\mathrm{K}_{2} \mathrm{O}$ applied to the bottom of the groove. In the ratoon, the plots received $500 \mathrm{~kg} \mathrm{ha}^{-1}$ of the formula 20-05-25.

\subsection{Experimental Design}

The experimental design was a randomized block, with five replications. The treatments consisted of four varieties of sugarcane: RB867515, RB92579, SP813250 and VAT90212. The cultivars were planted in plots with six grooves of 10.0 meters in length, spaced of 1.0 meter, totaling $60 \mathrm{~m}^{2}$ of total area. The four central lines with six meters in length were considered useful area of each plot ( $2 \mathrm{~m}$ at each ending area was discarded), making up $24 \mathrm{~m}^{2}$.

The varieties used were chosen because of their high productivity and industrial quality (Silva et al., 2017b, $2017 \mathrm{c}$ ), as well as the high significance, which represented over $50 \%$ of the total area planted in the Brazilian Northeast in the year prior to the implantation of the experiment (Silva et al., 2018).

\subsection{Variables Analyzed}

To study the nutritional requirement of sugarcane varieties RB867515, RB92579, SP813250 and VAT90212, the biomass productivity and the nutrient accumulation were determined in the first and second ratoon cane cycles. For the evaluations, samples were taken in the useful area of the plots, determinations were made on maturation, in the plant cane at 14 months after planting, at the first ratoon at 12 months after cutting the cane-plant and at the second ratoon at 12 months after cutting the first ratoon. 


\subsubsection{Biomass Productivity of Sugarcane Varieties}

Biomass productivity was determined in the field by weighing the aerial part (pointers, leaves and stems) of plants contained in $2.4 \mathrm{~m}^{2}$ of each experimental plot, becoming the sequence in the production per hectare $(\mathrm{t}$ $\left.\mathrm{ha}^{-1}\right)$.

\subsubsection{Nutritional Requirement of Sugarcane Varieties}

After determination of the biomass yield, the samples of fresh plant material were crushed in a forage chopper, and then moist subsamples were collected. In the laboratory, the subsamples were dried in forced air ventilation oven at $65^{\circ} \mathrm{C}$ until constant mass and again weighed to determine the moisture of the material.

After obtaining the dry matter, the subsamples were passed in a Willey mill, to determine the concentration of nutrients followed by methods described by Malavolta et al. (1997). N was extracted by sulfur digestion and determined by titration. The other nutrients were extracted by nitric-chloride digestion. $\mathrm{P}$ was determined calorimetrically by reduction of the phospho-molybdic complex. The $\mathrm{K}, \mathrm{Ca}$ and $\mathrm{Mg}$ by the atomic absorption spectrophotometry method and the $\mathrm{S}$ by the method of barium sulfate.

The extraction of nutrients by aerial part of the varieties was calculated by the product of the dry matter, concentration of the nutrients, and the results are presented in a study by Silva et al. (2017a). The nutritional requirement was estimated according to Oliveira et al. (2010) by dividing the mass of nutrients accumulated in the aerial part and the yield of stalks of each variety.

\subsection{Statistical Analyzes}

The data were analyzed using the Sisvar software (Ferreira, 2011), the variables submitted to the analysis of variance by the Test $\mathrm{F}$ and for those in which the $\mathrm{F}$ was significant, the means were compared by the Scott Knott test at $5 \%$ probability.

\section{Results and Discussion}

\subsection{Natural Biomass Productivity of the Sugarcane Area}

Sugarcane cultivars were similar for biomass yields in the three harvests, with 158,128 and $107 \mathrm{t} \mathrm{ha}^{-1}$ in the first and second ratoon cane-plant cycles, respectively (Figure 3). There was a decrease in the biomass yield of $30 \mathrm{t}$ compared to the first ratoon and cane-plant, and from $21 \mathrm{t}$ from the first to the second ratoon, this reduction between successive cycles has been reported in the literature (Gava et al., 2013; Silva et al., 2017b). This fact is possibly related to the genetic aspects of the cultivars and the interactions of the genotypes with the environment in which they are inserted (Silva et al., 2017c). Inherent factors such as sprouting, cane-age, and root activity may affect productivity decrease (Manhães et al., 2015; Cabral et al., 2017). In addition to environmental attributes such as luminosity, availability of water and mineral nutrients that can negatively influence sugarcane yield (Silva et al., 2017a).

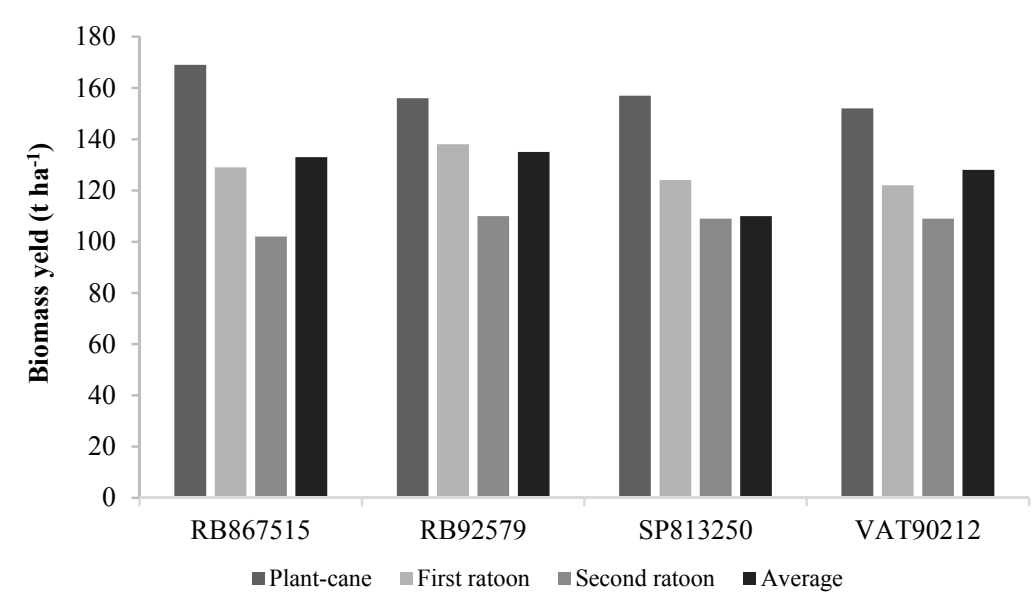

Figure 3. Productivity of biomass of sugarcane varieties in three crop cycles

Bezerra et al. (2017) evaluated the yield of fresh matter of the varieties RB863129, RB943655 and RB98710 in the cane-plant cycle cultivated in the Brazilian semi-arid region, and accumulations ranged from 91 to $99 \mathrm{t} \mathrm{ha}^{-1}$, 
about 30\% lower than those obtained in the present study. Benett et al. (2013) in a study conducted with RB867515 cultivated in a Red Ultisol obtained yields of stalks that varied from 90 to $104 \mathrm{t} \mathrm{ha}^{-1}$, considering that the stems correspond to approximately $80 \%$ of the natural matter, biomass productivity estimation was approximately $130 \mathrm{t} \mathrm{ha}^{-1}$. Silva et al. (2017a) evaluated the growth of the variety RB967515 in the first three harvest cycles, and verified a productivity of 72,63 and $67 \mathrm{t} \mathrm{ha}^{-1}$ for plant-cane, first and second ratoon, respectively, therefore inferior to those obtained in the present study.

Our results demonstrated that the genotypes used are of high productive potential, since they demonstrated a biomass accumulation considered from medium to high for the Brazilian Northeast, where the maximum growth phase of sugarcane occurs in short days and with cloudiness (Oliveira et al., 2011). The non-coincidence of the maximum water availability with the luminous reduces the photosynthetic rates, resulting in lower productivity in the Brazilian Northeast when compared to the Center-South (Oliveira et al., 2014).

\subsection{Macronutrients Requirement}

The varieties analyzed were similar in macronutrient requirements (Figure 4). For cane-plant cycle they presented the following order of requirement: $\mathrm{K}>\mathrm{N}>\mathrm{Ca}>\mathrm{Mg}>\mathrm{S}>\mathrm{P}$, in the first and second regrowth the sequence observed was $\mathrm{K}>\mathrm{N}>\mathrm{Ca}>\mathrm{S}>\mathrm{Mg}>\mathrm{P}$ (Figure 4). Our results confirm those of Franco et al. (2007) in a study with the cultivar SP80-1842 in the cane-plant cycle, and those of Bennett et al. (2013) in the first regrowth. On the other hand, Zambrosi (2012), studying the variety SP81-3250, in a Red-Yellow Oxisol, found, for second regrowth, the following order of nutrient extraction $\mathrm{N}>\mathrm{K}>\mathrm{Ca}>\mathrm{Mg}>\mathrm{P}>\mathrm{S}$.

The varieties showed similar $\mathrm{N}$ requirements in the three evaluation cycles, on average $1.35 \mathrm{~kg} \mathrm{~N}$ per ton of cane in the cane-plant, 0.87 and $0.73 \mathrm{~kg} \mathrm{t}^{-1}$ in the first and second regrowth, respectively (Table 2). Compared to the other macronutrients, $\mathrm{N}$ was the second most demanded (Figure 4). The high demand is justified by its participation in several cellular components, including chlorophyll, amino acids and nucleic acids (Taiz et al., 2017). There are many studies in the literature that demonstrate the importance of $\mathrm{N}$ in the sugarcane crop (Teodoro et al., 2013; Costa et al., 2016). The nutrient constitutes less than 1\% of sugarcane biomass, but its deficiency causes a reduction in the synthesis of chlorophyll, essential amino acids and the energy required to produce carbohydrates and carbon skeletons, directly reflecting the development and yield of the crop (Taiz et al., 2017).

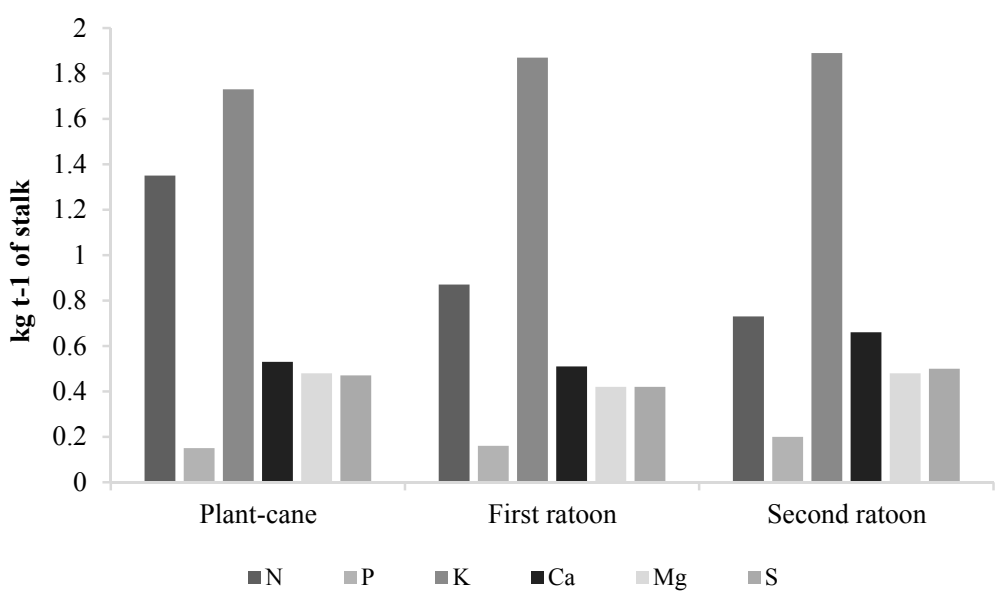

Figure 4. Average macronutrient requirement of four sugarcane varieties in three crop cycles

Despite the high demand for $\mathrm{N}$ in Brazil, sugar cane is grown at relatively low doses $\left(90-120 \mathrm{~kg} \mathrm{ha}^{-1}\right)$, when compared to other producing countries, the quantities of $\mathrm{N}$ applied can be up to $100 \%$ higher the doses used in Brazil (Cantarella et al., 2007), this is related to the cane-plant response to $\mathrm{N}$ being small and usually occur only in low doses (Fortes et al., 2013). In the present study, only $50 \mathrm{~kg} \mathrm{ha}^{-1}$ was applied to cane-plant, this dose, although low, conditioned a high productivity of natural biomass $\left(158 \mathrm{t} \mathrm{ha}^{-1}\right)$, possibly the application of limestone and soil preparation on occasion installation of the study stimulated the increase of the microbial activity of the soil resulting in a higher rate of mineralization of the organic matter of the soil, especially of the cultural remains and rhizomes of the previous crop. (Table 1), results in higher efficiency of the plants in the nitrogen absorption (Silva et al., 2017b). 
Phosphorus was the macronutrient that the varieties required in less quantity $0.15 ; 0.16$ and $0.20 \mathrm{~kg} \mathrm{t}^{-1}$ of cane in the plant cane, first and second regrowth respectively. Oliveira et al. (2016) evaluated the nutritional requirements of 11 sugarcane varieties in the cane-plant cycle, and obtained for SP813250, RB867515 and RB92579, requirements of $0.42 ; 0.50$ and $0.39 \mathrm{~kg} \mathrm{t}^{-1}$ of stem, respectively. For the first ratoon Leite et al. (2016) observed that the varieties SP81-3250, SP89-1115 and RB855453 require on average $0.24 \mathrm{~kg}$ of P per ton of stalk.

Table 2. Extraction of nitrogen $(\mathrm{N})$ and phosphorus $(\mathrm{P})$ in different varieties of sugarcane for each one ton of stems produced $(\mathrm{TCH})$

\begin{tabular}{|c|c|c|c|c|c|c|c|c|}
\hline \multirow{2}{*}{ Varieties } & \multicolumn{4}{|c|}{ Nitrogen $\left(\mathrm{kg} \mathrm{t}^{-1}\right)$} & \multicolumn{4}{|c|}{ Phosphorus $\left(\mathrm{kg} \mathrm{ha}^{-1}\right)$} \\
\hline & Plant-cane & First ratoon & Second ratoon & Average & Plant-cane & First ratoon & Second ratoon & Average \\
\hline VAT90212 & $1.12 \mathrm{a}$ & $0.93 \mathrm{a}$ & $0.81 \mathrm{a}$ & 1.01 & $0.16 \mathrm{a}$ & $0.16 \mathrm{a}$ & $0.17 \mathrm{a}$ & 0.17 \\
\hline SP813250 & $1.31 \mathrm{a}$ & $0.81 \mathrm{a}$ & $0.78 \mathrm{a}$ & 0.97 & $0.15 \mathrm{a}$ & $0.17 \mathrm{a}$ & $0.20 \mathrm{a}$ & 0.17 \\
\hline RB867515 & $1.41 \mathrm{a}$ & $0.81 \mathrm{a}$ & $0.63 \mathrm{a}$ & 0.95 & $0.17 \mathrm{a}$ & $0.15 \mathrm{a}$ & $0.23 \mathrm{a}$ & 0.18 \\
\hline RB92579 & $1.36 \mathrm{a}$ & $0.95 \mathrm{a}$ & $0.70 \mathrm{a}$ & 1.00 & $0.13 \mathrm{a}$ & $0.13 \mathrm{a}$ & $0.19 \mathrm{a}$ & 0.15 \\
\hline Average & 1.35 & 0.87 & 0.73 & 0.98 & 0.15 & 0.16 & 0.20 & 0.17 \\
\hline
\end{tabular}

Note. Means followed by the same letter do not differ statistically by Scott-Knott test at 5\% probability.

Phosphorus, although required in much smaller quantities than nitrogen and potassium, has a great effect on productivity in terms of plant mass and sugar, since phosphorus is a vital component of photosynthesis, where it participates in the conversion of solar energy in chemical energy and, later, in the transfer of energy to vital processes. In sugarcane, it plays an important role in cell enlargement and the transfer of genetic information (Taiz et al., 2017). Besides the metabolic importance, for sugarcane, phosphorus is important in the industrialization of the broth, positively influencing the clarification. Low-phosphorus broths are difficult to flocculate, damaging the decantation of impurities, which in turn will produce lower quality sugar and lower economic value (Mahadevaiah et al., 2007).

The $\mathrm{K}$ was the nutrient required in higher amounts in the three crop cycles, demonstrating a requirement of 1.73, 1.87 and $1.89 \mathrm{~kg} \mathrm{t}^{-1}$ of shoots in the cane-plant, first and second regrowth, respectively (Table 3). The highest requirement of this nutrient in sugarcane cultivation has been reported in the literature (Oliveira et al., 2010; Oliveira et al., 2011). Oliveira et al. (2010) in a study with 11 varieties in the cane-plant cycle verified on average that each ton of stalk produced is absorbed by the plant and removed with the crop $1.72 \mathrm{~kg}$ of potassium. Pancelli et al. (2015) verified for the first regrowth of RB867515 a requirement of $0.98 \mathrm{~kg} \mathrm{of} \mathrm{K} \mathrm{t}^{-1}$ of sugarcane, which corresponds to half of the requirement observed in the present study. Cavalcante et al. (2016) verified potassium accumulations in the aerial part of SP 93-3046 that reach up to $192 \mathrm{~kg} \mathrm{ha}^{-1}$ for a yield of $120 \mathrm{tha}$.

The high dependence of potassium by sugarcane is explained by the important role as metabolic activator of many metabolic processes related to photosynthesis, osmoregulation, respiration, nitrogen absorption, protein and starch synthesis (Marschener et al., 2012). Potassium also influences the industrial quality of cane, when the nutrient is high in the plant, there is a delay in the maturation of sugarcane, proportionally increasing the contents of reducing sugars and the ashes of the broth that hinder the crystallization of the sugar and reduce the purity of the sugar sucrose obtained (Silva et al., 2017d).

Table 3. Extraction of potassium $(\mathrm{K})$ and calcium $(\mathrm{Ca})$ in different varieties of sugarcane required to produce one ton of stems $(\mathrm{TCH})$

\begin{tabular}{|c|c|c|c|c|c|c|c|c|}
\hline \multirow{2}{*}{ Varieties } & \multicolumn{4}{|c|}{ Potassium $\left(\mathrm{kg} \mathrm{t}^{-1}\right)$} & \multicolumn{4}{|c|}{ Calcium $\left(\mathrm{kg} \mathrm{ha}^{-1}\right)$} \\
\hline & Plant-cane & First ratoon & Second ratoon & Average & Plant-cane & First ratoon & Second ratoon & Average \\
\hline VAT90212 & $1.82 \mathrm{a}$ & $1.86 \mathrm{a}$ & $1.92 \mathrm{a}$ & 1.88 & $0.54 \mathrm{a}$ & $0.52 \mathrm{a}$ & $0.58 \mathrm{a}$ & 0.54 \\
\hline SP813250 & $1,72 \mathrm{a}$ & $1.91 \mathrm{a}$ & $1.80 \mathrm{a}$ & 1.81 & $0.57 \mathrm{a}$ & $0.49 \mathrm{a}$ & $0.67 \mathrm{a}$ & 0.58 \\
\hline RB867515 & $1.80 \mathrm{a}$ & $1.88 \mathrm{a}$ & $1.81 \mathrm{a}$ & 1.83 & $0.51 \mathrm{a}$ & $0.53 \mathrm{a}$ & $0.76 \mathrm{a}$ & 0.60 \\
\hline RB92579 & $1.59 \mathrm{a}$ & $1.83 \mathrm{a}$ & $1.98 \mathrm{a}$ & 1.80 & $0.49 \mathrm{a}$ & $0.51 \mathrm{a}$ & $0.63 \mathrm{a}$ & 0.54 \\
\hline Average & 1.73 & 1.87 & 1.89 & 1.83 & 0.53 & 0.51 & 0.66 & 0.57 \\
\hline
\end{tabular}

Note. Averages followed by the same letter in the column do not differ statistically by Scott-Knott test at 5\% probability. 
The varieties were similar in the Ca requirement, and evidenced for the production of one ton of sugarcane a requirement of $0.53,0.51$ and $0.66 \mathrm{~kg}$ of $\mathrm{Ca}$ in the plant-cane cycles, first and second regrowth, respectively. After high potassium and nitrogen, calcium has been the macronutrient most accumulated by sugarcane (Franco et al., 2007; Zambrosi et al., 2012; Benett et al., 2013), its high demand stems from its structural role in which $\mathrm{Ca}^{2+}$ binds to acidic groups of membrane lipids (phospho and sulfulipids) and to cross-links between pectins, particularly in the lamella medium recently dividing cells; and its signaling role, in which $\mathrm{Ca}^{2+}$ acts as a secondary messenger that initiates the plant responses to environmental stimulation. Also as a secondary messenger, $\mathrm{Ca}^{2+}$ can bind to calmodulin, a protein found in the plant cell cytosol. The calmodulin- $\mathrm{Ca}^{2+}$ complex then binds to different types of proteins, including kinases, phosphatases, secondary signaling messenger proteins, and cytoskeletal proteins. Thus, it regulates many cellular processes, from transcription control and cellular survival to the release of chemical signals (Taiz et al., 2017).

$\mathrm{Mg}$ requirements for production of one ton of cane were obtained, ranging from $0.48 \mathrm{~kg}$ of $\mathrm{Mg}$ in cane-plant to $0.42 \mathrm{of} \mathrm{Mg}$ in the first regrowth (Table 4). Oliveira et al. (2010) observed for varieties RB9279, SP813250, RB8575150 in the plant-cane cycle a requirement of Mg of $0.48 ; 0.43$ and $0.48 \mathrm{~kg} \mathrm{t}^{-1}$, respectively. Coleti et al. (2006) found in the first regrowth of RB835486 and SP813250 nutritional requirements ranging from 0.13 to $0.26 \mathrm{~kg} \mathrm{t}^{-1}$. The high importance of Mg for sugarcane stems from being a major enzymatic activator in plants, among which are those involved in energy transfer via (ATP). In addition, the $\mathrm{Mg}^{2+}$ participates in the activation of enzyme kinases and most of the reactions that act on the transfer of $\mathrm{P}$.

Considering that the levels of $\mathrm{Ca}$ and $\mathrm{Mg}$ in the soil before the installation of the study (Table 1) were above the critical limits established by Oliveira et al. (2007) and that dolomitic limestone $(>12 \% \mathrm{MgO})$ was applied in a dose sufficient to raise base saturation to $60 \%$, we expect that the plants had no limitation on the supply of this secondary macronutrients.

Table 4. Extraction of magnesium $(\mathrm{Mg})$ and sulfur $(\mathrm{S})$ in different varieties of sugarcane required to produce one ton of stalks $(\mathrm{TCH})$

\begin{tabular}{|c|c|c|c|c|c|c|c|c|}
\hline \multirow{2}{*}{ Varieties } & \multicolumn{4}{|c|}{ Magnesium $\left(\mathrm{kg} \mathrm{t}^{-1}\right)$} & \multicolumn{4}{|c|}{ Sulfur $\left(\mathrm{kg} \mathrm{t}^{-1}\right)$} \\
\hline & $\mathrm{CP}$ & FR & SR & Average & $\mathrm{CP}$ & PR & SR & Average \\
\hline VAT90212 & $0.48 \mathrm{a}$ & $0.39 \mathrm{a}$ & $0.47 \mathrm{a}$ & 0.45 & $0.42 \mathrm{a}$ & $0.38 \mathrm{a}$ & $0.47 \mathrm{a}$ & 0.42 \\
\hline SP813250 & $0.48 \mathrm{a}$ & $0.46 \mathrm{a}$ & $0.47 \mathrm{a}$ & 0.47 & $0.51 \mathrm{a}$ & $0.47 \mathrm{a}$ & $0.54 \mathrm{a}$ & 0.51 \\
\hline RB867515 & $0.49 \mathrm{a}$ & $0.45 \mathrm{a}$ & $0.45 \mathrm{a}$ & 0.46 & $0.48 \mathrm{a}$ & $0.39 \mathrm{a}$ & $0.46 \mathrm{a}$ & 0.44 \\
\hline RB92579 & $0.46 \mathrm{a}$ & $0.37 \mathrm{a}$ & $0.52 \mathrm{a}$ & 0.45 & $0.47 \mathrm{a}$ & $0.44 \mathrm{a}$ & $0.53 \mathrm{a}$ & 0.48 \\
\hline Average & 0.48 & 0.42 & 0.48 & 0.46 & 0.47 & 0,42 & 0,50 & 0,46 \\
\hline
\end{tabular}

Note. Means followed by the same letter do not differ statistically by Scott-Knott test at $5 \%$ probability.

For S, similar nutrient requirement value was observed in the first and second regrowth requirements of 0.47 , 0.42 and $0.50 \mathrm{~kg} \mathrm{t}^{-1}$ of stem yield, respectively (Table 4). Orlando Filho et al. (1980) obtained for CB41-76 in the cane-plant cycle $\mathrm{S}$ requirement of $0.84 \mathrm{~kg} \mathrm{t}^{-1}$, whereas Coleti et al. (2006) obtained for the first regrowth of RB835486 and SP813250 average requirement of $0.18 \mathrm{~kg} \mathrm{t}^{-1}$ of stem produced.

\section{Conclusion}

The sugarcane varieties RB92579, SP813250, VAT90212 and RB857515, presented high productive potential and resemble the accumulation of natural biomass and macronutrient demand.

\section{References}

Belle, C., Kulczynski, S., Kuhn, P. R., Donini, L. P., \& Gomes, C. B. (2017). Reaction of sugarcane genotypes to parasitism of Meloidogyne javanica and Pratylenchus zeae. Revista Caatinga, 30(2), 530-535. https://doi.org/10.1590/1983-21252017v30n229rc

Benett, C. G. S., Buzetti, S., Silva, K. S., Teixeira Filho, M. C. M., Costa, N. R., Maeda, A. S., \& Andreotti, M. (2013). Quantidade de nutrientes na haste da cana-de-açúcar em função das fontes e doses de manganês. Semina: Ciências Agrárias, 34 (3), 1077-1088. https://doi.org/10.5433/1679-0359.2013v34n3p1077

Bezerra, J. D. C., Ferreira, G. D. G., Campos, J. M. D. S., Oliveira, M. W. D., Andrade, A. P. D., \& Nascimento Júnior, J. R. S. D. (2017). Biometric and chemical characteristics of sugarcane varieties for use as forage in limiting soil water conditions. Revista Brasileira de Zootecnia, 46(5), 384-392. https://doi.org/10.1590/ s1806-92902017000500003 
Cabral, P. D. S., Nunes, J. A. R., Zuchi, J., Raizer, A. J., \& Paula, T. O. M. (2017). Implications of the clone by harvest interaction in the selection of sugarcane genotypes in a regionalized program. Genetics and Molecular Research, 16(2), 1-11. https://doi.org/10.4238/gmr16029660

Calheiros, A. S., Oliveira, M. W., Ferreira, V. M., Barbosa, G. V. S., Costa, J. P. V., Lima, G. S. A., \& Aristides E. V. S. (2011). Acúmulo de nutrientes e produção de sacarose de duas variedades de cana-de-açúcar na primeira rebrota, em função de doses de fósforo. STAB. Açúcar, Álcool \& Subprodutos, 29(1), 26-29.

Cantarella, H., Trivelin, P. C. O., \& Vitti, A. C. (2007). Nitrogênio e enxofre na cultura da cana-de-açúcar. In T. Yamada, S. R. S. Abdalla, \& G. C. Vitti (Eds.), Nitrogênio e Enxofre na Agricultura Brasileira (pp. 349-412). Piracicaba: International Plant Nutrition Institute.

Cavalcante, V. S., Prado, R. M., Almeida, H. J., Silva, T. M. R., Flores, R. A., \& Pancelli, M. A. (2016). Potassium nutrition in sugar cane ratoons cultured in red latosol with a conservationist system. Journal of Plant Nutrition, 39(3), 315-322. https://doi.org/10.1080/01904167.2015.1009111

Coleti, J. T., Casagrande, J. C., Stupiello, J. J., Ribeiro, L. D., \& Oliveira, G. R. (2006). Remoção de macronutrientes pela cana-planta e cana-soca, em Argissolo, variedades RB83486 e SP81-3250. Stab, 24, 32-36.

Embrapa (Empresa Brasileira de Pesquisa Agropecuária). (2009). Manual de análise química de solo, planta e fertilizantes (p. 627). Embrapa, Brasília.

Embrapa (Empresa Brasileira de Pesquisa Agropecuária). (2013). Sistema brasileiro de classificação de solos (p. 353). Embrapa, Brasília.

Ferreira, D. F. (2011). Sisvar: A computer statistical analysis system. Cienc Agrotec., 35(6), $1039-1042$. https://doi.org/10.1590/S1413-70542011000600001

Fortes, C., Trivelin, P. C. O., Vitti, A. C., Ferreira, D. A., Franco, H. C. J., \& Otto, R. (2011). Recovery of nitrogen $(15 \mathrm{~N})$ by sugarcane from previous crop residues and urea fertilisation under a minimum tillage system. Sugar Tech, 13(1), 42-46. https://doi.org/10.1007/s12355-011-0074-4

Franco, H. C. J., Bolonga, I. R., Faroni, C. E., Vitti, A., \& Trivelin, P. C. O. (2007). Acúmulo de macronutrientes em cana-de-açúcar em função da adubação nitrogenada e dos resíduos culturais incorporados ao solo no plantio. Bragantia, 66(4), 669-674. https://doi.org/10.1590/S0006-87052007000400017.

Gava, G. D. C., Silva, M. D. A., Silva, R. D., Jeronimo, E. M., Cruz, J. C., \& Kölln, O. T. (2011). Produtividade de três cultivares de cana-de-açúcar sob manejos de sequeiro e irrigado por gotejamento. Revista Brasileira de Engenharia Agrícola e Ambiental, 15(3), 250-255. https://doi.org/10.1590/S1415-43662011000300005

Leite, J. M., Ciampitti, I. A., Mariano, E., Vieira-Megda, M. X., \& Trivelin, P. C. (2016). Nutrient Partitioning and Stoichiometry in Unburnt Sugarcane Ratoon at Varying Yield Levels. Frontiers in Plant Science, 7, 466. https://doi.org/10.3389/fpls.2016.00466

Mahadevaiah, M. S., Kumar, Y., Galil, M. S. A., Suresha, M. S., Sathish, M. A., \& Nagendrappa, G. A. (2007). simple spectrophotometric determination of phosphate in sugarcane juices, water and detergent samples. E-Journal of Chemistry, 4(1), 467-473. https://doi.org/10.1155/2007/576560

Malavolta, E., Vitti, G. C., \& Oliveira, A. S. (1997). Avaliação do estado nutricional das plantas-Princípio e aplicações (p. 319). ABPPF, Piracicaba.

Manhães, C. M. C., Garcia, R. F., Francelino, F. M. A., Oliveira, F. H., \& Coelho, F. C. (2015). Fatores que afetam a brotação e o perfilhamento da cana-de-açúcar. Vértices, 17(1), 163-181. https://doi.org/10.5935/ 1809-2667.20150011

Marschener, P. (2012). Mineral Nutrition of higher plants (3rd ed., p. 651). Elsevier, San Diego.

Oliveira, E. C. A., Freire, F. J., Oliveira, A. C. D., Simões Neto, D. E., Rocha, A. T. D., \& Carvalho, L. A. D. (2011) Productivity, water use efficiency, and technological quality of sugarcane subjected to differents water regimes. Pesquisa Agropecuária Brasileira, 46(6), 617-625. https://doi.org/10.1590/S0100-204X2011 000600007

Oliveira, E. C. A., Freire, F. J., Oliveira, R. I. D., Freire, M. B. G. S., Simões Neto, D. E., \& Silva, S. A. M. D. (2010). Extração e exportação de nutrientes por variedades de cana-de-açúcar cultivadas sob irrigação plena. Revista Brasileira de Ciência do Solo, 34(4), 1343-1352. https://doi.org/10.1590/S0100-06832010000 400031 
Oliveira, M. W., Freire, F. M., Macêdo, G. A. R., \& Ferreira, J. J. (2007). Nutrição mineral e adubação da cana-de-açúcar. Informe Agropecuário, 28(1), 30-43.

Oliveira, M. W., Silva, V. S. G., Oliveira, D. C., Silva, J. C. T., \& Reis, R. M. S. (2012). Production and forage quality of two sugarcane varieties affected by fertilization with copper and manganese. Revista Cientifica de Produção Animal, 14(2), 165-168. https://doi.org/10.15528/2176-4158/rcpa.v14n2p165-168

Oliveira, M. W., Silva, V. S. G., Reis, L. S., Oliveira, D. C., \& Silva, J. C. T. (2014). Produção e qualidade de três variedades de cana-de-açúcar cultivadas no Nordeste de Minas Gerais. Revista Ciência Agrícola, 12(1), $17-20$.

Oliveira, R. I., Medeiros, M. R. F. A., Freire, C. S., Freire, F. J., Simões Neto, D. E. S., \& Oliveira, E. C A. (2016). Nutrient partitioning and nutritional requirement in sugarcane. Australian Journal of Crop Science, 10(1), 69-75.

Orlando Filho, J., Haag, H. P., \& Zambello Junior, E. (1980). Crescimento e absorção de macronutrientes pela cana-de-açúcar, variedade CB41-76, em função da idade, em solos do estado de São Paulo. Boletim Técnico PLANALSUCAR, 2 (p. 128). São Paulo, IAA.

Pancelli, M. A., Prado, R. M., Flores, R. A., Almeida, H. J., Moda, L. R., \& Souza Junior, J. P. (2015). Growth, yield and nutrition of sugarcane ratoon as affected by potassium in a mechanized harvesting system. Australian Journal of Crop Science, 9(10), 915-924.

Santos, L. A., Souza, J. E. A., Barboza, A. S. R., Silva, V. S. G., \& Clemente, P. R. A. (2016). Potencial energético da biomassa de cana-de-açúcar em uma usina sucroenergética. Revista da Universidade Vale do Rio Verde., 14(2), 1101-1108. https://doi.org/10.5892/ruvrd.v14i2.3027

Silva, S. F., Olivares, F. L., \& Canellas, L. P. (2017a). The biostimulant manufactured using diazotrophic endophytic bacteria and humates is effective to increase sugarcane yield. Chemical and Biological Technologies in Agriculture, 4(1), 24. https://doi.org/10.1186/s40538-017-0106-8

Silva, V. S. G., Oliveira, M. W., Oliveira, D. C., Oliveira, T. B. A., Pereira, M. G., \& Nogueira, C. H. C. (2017b). Nutritional diagnosis of sugarcane varieties in a Yellow Oxisol during three agricultural seasons. African Journal of Agricultural Research, 12(1), 50-57. https://doi.org/10.5897/ AJAR2016.11865

Silva, V. S. G., Oliveira, M. W., Pereira, M. G., Oliveira, T. B. A., Nogueira, C. H. C., Brito, F. S., \& Franco Jr., C. L. (2018). Nutrient contents in sugarcane biomass in the first regrowth cycle. Journal of Agricultural Science, 10(3), 325-332. https://doi.org/10.5539/jas.v10n3p325

Silva, V. S. G., Oliveira, M. W., Oliveira, T. B. A., Mantovanelli, B. C., Silva, A. C. I., Soares, A. N. R., \& Clemente, P. R. A. (2017c). Leaf area of sugarcane varieties and their correlation with biomass productivity in three cycles. African Journal of Agricultural Research, 12(7), 459-466. https://doi.org/10.5897/ AJAR2016.11817

Silva, V. S. G., Oliveira, M. W., Silva, A. C., Silva, A. F., Galvão, E. R., \& Santana, M. B. (2017d). Agro-industrial quality in plant, first and second ratoon crops of sugarcane varieties. Aust. J. Crop Sci., 9(10), 915-924. https://doi.org/10.21475/ajcs.17.11.09.pne688

Taiz, L., Zeiger, E., Moller, I. M., \& Murphy, A. (2017). Fisiologia e desenvolvimento vegetal (6th ed., p. 888). Porto Alegre: Artmed.

Teodoro, I. T., Dantas Neto, J. D., de Souza, J. L., Lyra, G. B., Brito, K. S., Sá, L. A., ... Sarmento, P. L. V. S. (2013). Isoquantas de Produtividade da Cana-de-açúcar em Função de Níveis de Irrigação e Adubação Nitrogenada. Irriga, 18(3), 387. https://doi.org/10.15809/irriga.2013v18n3p387

Zambrosi, F. C. B. (2012). Phosphorus fertilization in sugarcane ratoon and its interaction with magnesium. Bragantia, 71(3), 400-405. https://doi.org/10.1590/S0006-87052012005000029

\section{Copyrights}

Copyright for this article is retained by the author(s), with first publication rights granted to the journal.

This is an open-access article distributed under the terms and conditions of the Creative Commons Attribution license (http://creativecommons.org/licenses/by/4.0/). 